\title{
Potential Usage of Some of the Ground-Cover Vegetation for Ecosystem Restoration Practices in Central Anatolian Region of Turkey
}

Oktay Yildiz ( $\square$ oktayyildiz@duzce.edu.tr)

Duzce University

Ernaz Altundag

Duzce University

\section{Research Article}

Keywords: Aridland, restoration, Turkey, ground-cover

Posted Date: March 23rd, 2021

DOl: https://doi.org/10.21203/rs.3.rs-347488/v1

License: (c) (1) This work is licensed under a Creative Commons Attribution 4.0 International License.

Read Full License 


\section{Abstract}

Long-term animal grazing and agricultural practices have disturbed the vegetation cover and rendered the sites prone to erosion in Central Anatolia Region. Plantation practices have been carried out for about six decades in the region. However, tree-oriented plantation practices have not shown promising results. Thus, experimental data gathered in the region using new approaches with different plant species are urgently needed. The aim of the current study is to evaluate potential usage of some of the ground-cover species for ecosystem restoration in the region.

Seeds of fifteen local species were collected during extensive field surveys during summer and early fall of 2012 and 2013. Five sites scattered on the basin were chosen as experimental blocks. The area covers the driest part of the region with less than $300 \mathrm{~mm}$ annual precipitation and $11 \mathrm{C}^{0}$ average temperature. Soil texture for the first-20-cm soil depth in the experimental units ranges from clay to sandy clay loam with a high lime content. In October 2012, April 2013, October 2013 and April 2014 seeds of these fifteen species were sown on three $40 \mathrm{~cm} \times 600-\mathrm{cm}$ beds.

In the spring and summer of 2013 and 2014, sites were visited, and field emergence rates and seedling growth were recorded. Atriplex hortensis (L.), Peganum harmala (L.), Glaucium corniculatum (L.), Marrubium parviflorum (Fisch.\&C.A.Mey.), Onobrychis tournefortii ((Willd.) Desv.), Reseda lutea (L.), Stachys cretica (L.), Teucrium polium (L.) and Vicia cappodicica (Boiss. \& Bal.) appear to be the most promising ground-cover species for ecosystem restoration in the region.

\section{Introduction}

The Central Anatolian closed basin extends between the North Anatolian Mountain line in the North and the Taurus Mountains in the South and has a continental climate. Due to low precipitation and low biological activity, soils in the region remain at the early development stages, and their properties are largely determined by parent material (Uslu 1971; Tunçdilek 1987; Atalay 2002; Kapur et al. 2002; Özhatay et al. 2003). Shallow soils and persistent summer drought lead to steppe, the typical vegetation formation in the region. These drylands are environmentally fragile and thus very susceptible to degradation. Longterm animal grazing and conversion of marginal sites into agricultural practices have disturbed the vegetation cover, rendering the sites prone to erosion. These disturbed or degraded ecosystems are characterized by poor soil fertility, shortage of water and deteriorated microenvironment, which would severely restrict their productivity (Day and Detling 1994; Varnamkhasti et al. 1995). Recurrent disturbance of ground cover leads to significant loss of productive top soil and associated microorganisms. Thus, plant cover composition has changed dramatically. The remaining plant communities consist mainly of herbs and shrub species, which can resist long-term drought and are often unpalatable (Uslu 1971; Tunçdilek 1987; Atalay 2002; Özhatay et al. 2003).

The lack of natural vegetation as windbreaks has resulted in an increased evaporation and water deficiency due to constantly blowing winds in the vast plains. During dry periods, fine grained and loose 
soil particles are easily mobilized and transported over long distances (Richards 1954; Balcl 1978; Birkman 1976; Hillel 1998; Brady and Weil 1999). As a result, about half of the Central Anatolia is under the influence of wind and water erosion (T.C. Çevre ve Orman Bakanlığı 2005 and 2008).

In the 1960s, the Turkish government launched an afforestation action program to reclaim these degraded lands. According to the Ministry of Forestry and Water Affairs, nearly 900 thousand hectares of land were afforested for soil protection by 2010 (T.C. Çevre ve Orman Bakanlığı 2008). There still is more than five million hectares of potential land that is technically, socially and ecologically feasible for afforestation in Turkey (T.C. Çevre ve Orman Bakanlığı 2005 and 2008). An important part of these areas is in arid and semi-arid regions. Afforestation success in these infertile soils is limited. Since seedlings cannot acquire enough water and survival and growth rate are very low (Irmak 1963; Uslu 1971; T.C. Çevre ve Orman Bakanlığı 2005 and 2008).

Soil protection, erosion control and greenbelt plantation practices have been commonly utilized for nearly six decades in the region. Since the main focus of these practices is the establishment of trees, the success rate was assessed by tree survival and growth. Long-practiced tree planting has not showed significant success. Restoration practices on these marginal sites should not be limited to planting trees to prevent soil erosion but also aim to establish microbial communities, their interactions and the other natural process in the rhizosphere. Therefore, the first step of restoration programs in these degraded lands should be the establishment of an herbaceous and shrub cover to improve soil organic matter and nutrient content. Beginning with species of early seral stages may increase subsequent afforestation success (Heske 1952).

Restoration of these marginal sites should start with choosing the plant species that can germinate and thrive in limy and salty soils, adapted to aridity, and which will disseminate a large number of seeds, enrich the soil with organic matter and nutrients rather than putting the trees of the later seres in place (Irmak 1963; Balcı 1978; Thirgod 1982; Çetik 1985; Çepel 1995; Kapur et al. 2002).

Information on soil and nutrient cycling at different seral stages in these limy, salt affected and alkaline soils is very limited. Experimental data gathered in the region using new approaches with different plant species are urgently needed. Thus, the aim of the current study is to survey some of the ground-cover vegetation and to evaluate their potential usage for the restoration of degraded land and conducting field trials.

\section{Material And Methods}

\subsection{Site description}

The study was carried out in the Acıpınar, Incesu, Emirgazi, Sazlıpınar and Karapınar municipalities, scattered on about $3000 \mathrm{~km}^{2}$ in the Central Anatolia Basin and designated as afforestation sites by the General Directorate of Forestry. A randomized block design with five replications was employed for the

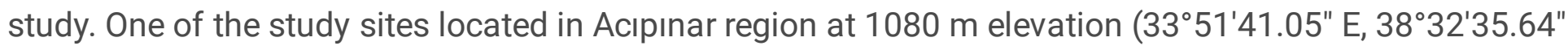


$\mathrm{N})$. The site is facing to the south aspect. The soil texture between the $0-20-\mathrm{cm}$ soil depth is loamy to silty clay loam. One of the sites located in the Incesu region ( $\left.33^{\circ} 46^{\prime} 50.47^{\prime \prime} \mathrm{E}, 38^{\circ} 11^{\prime} 52.78^{\prime \prime} \mathrm{N}\right)$ is located at $1000 \mathrm{~m}$ elevation. The soil texture is sandy loam to clay loam. Another site, Emirgazi is located at $1180 \mathrm{~m}$ elevation region ( $33^{\circ} 51^{\prime} 41.53^{\prime \prime} \mathrm{E}, 37^{\circ} 54^{\prime} 54.54^{\prime \prime} \mathrm{N}$ ) with $0-20$ percent slope. Soil texture ranges from sandy clay to loamy. One of the sites located in the Sazlıpınar region $\left(33^{\circ} 11^{\prime} 52.46^{\prime \prime} \mathrm{E}, 37^{\circ} 42^{\prime} 16.33^{\prime \prime} \mathrm{N}\right)$ at $980 \mathrm{~m}$ elevation. The Sazlıpınar site has clay loam on $0-20 \mathrm{~cm}$ soil depth. One of the sites is located at $970 \mathrm{~m}$ elevation in the Karapınar region $\left(33^{\circ} 28^{\prime} 52.34^{\prime \prime} \mathrm{E}, 37^{\circ} 43^{\prime} 48.95^{\prime \prime} \mathrm{N}\right)$. The soil texture for this site is sandy loam to clay loam.

The area presents varying geological conditions. Limestone, marn, claystone, conglomerate, sandstone, and gypsum are commonly distributed in the plain (Tunçdilek 1987; Kapur et al. 2002). Due to the climate and poor soil development, the water storage capacity of the soil is limited. Low precipitation and poor leaching caused accumulation of ions and carbonates in the upper soil profile (Dregne 1976; Buol et al. 1989; Fanning and Fanning 1989; Brady and Weil 1999). Thus, alkaline salty and sodic soils cover large areas. The soil bulk density in the first $20 \mathrm{~cm}$ soil depth averages $1.2 \mathrm{~g} \mathrm{~cm}^{-3}$ across all the sites. All of the sites have high lime content. The soil salinity on all sites is considered below the critical value (Table 1). Soil organic matter (OM) and nutrient content are very low with no significant variation among the sites (Table 1 and 2).

There are two meteorological stations in the vicinity of the experimental sites. The Acıpınar site is located $25-\mathrm{km}$ northwest of the Aksaray meteorological station whereas the Incesu experimental site is located $22-\mathrm{km}$ south of the same station. The Emirgazi site is located $15 \mathrm{~km}$ north of the Karapınar meteorological station. The Karapınar and Sazlıpınar experimental sites are located 15 and $40 \mathrm{~km}$ west of the Karapınar meteorological station, respectively. The prevailing continental climate calls forth moisture deficiency throughout the growing season in the region (Özyuvacı 1999; Atalay 2002). Ceylan et al. (2009) stated that the region is the driest part of Turkey and considered "very dry". This area covers the driest part of the region with less than $300 \mathrm{~mm}$ annual precipitation and $11 \mathrm{C}^{0}$ average temperatures. The Walter diagrams constructed based on 60 years of climatic data gathered from these two station indicate that the area where experimental plots are located experience a water deficiency from May to October (Walter 1970; Figs. 1a and b).

\subsection{Field Study}

Seeds of 15 species were collected during extensive field surveys in the summer and early fall of 2012 and 2013 (Table 3). The sites where the seeds were collected from are afforestation sites and excluded to herding for more than 10 years. The seeds were dried naturally and kept in a cool place in the laboratory until they were sown.

Soil has a hardpan at about 70-80 $\mathrm{cm}$ profile dept. Therefore, using ripper to break up the hardpan constitutes the main part of the site preparation practices for securing successful afforestation in the 
region. In summer 2012, the sites were ripped using a caterpillar tractor (135 HP) equipped with a threeshank ripper. Then the top-soil was tilled with a $4 \times 4$ rubber-tired tractor to prepare seeding beds.

In October 2012, April 2013, October 2013 and April 2014, for each species, three $40 \mathrm{~cm}$ x $600 \mathrm{~cm}$ beds were leveled using agricultural rakes. In the mid October 2012, after the first rains supply enough moisture to the soil, depending on the thousand seed weight equal amount of seeds were uniformly distributed on the beds with the help of a wooden frame (Table 3). Following sowing the seeds were covered manually. The same procedures were repeated in adjacent beds on each site in the early spring of $2013\left(1^{\text {st }}\right.$ week of April). The experiment was repeated in 2013 fall and 2014 spring for Atriplex hortensis (L.), Peganum harmala (L.), Glaucium corniculatum (L.), Marrubium parviflorum (Fisch.\&C.A.Mey.), Onobrychis tournefortii ((Willd.) Desv.), Reseda lutea (L.), Stachys cretica (L.), Teucrium polium (L.) and Vicia cappodicica (Boiss. \& Bal.)species which showed field emergence success for the previous year. From the third week of April 2014, the plots were visited three times with 7 days interval to observe the field emergence. The field emergence rate was obtained by counting the number of seedlings which had attained the two-leaf stage.

A 20- $\times 50-\mathrm{cm}$ wooden frames consisted of 20 equal quadrats with $5 \times 10 \mathrm{~cm}$ dimensions was placed on on each plot at the end of April. The number of seedlings in each quadrat were counted and ground cover estimation were recorded (Marsdena 2002).

\subsection{Sampling and analysis}

To determine soil properties, two sets of soil samples were taken from the first $20 \mathrm{~cm}$ soil depth on each site in October, 2012. The first set of soil is taken with $100 \mathrm{~cm}^{3}$ of soil core samplers (AMS Soil Core Sampler) and used to determine bulk density. Soil bulk density was calculated through the known volume of core and oven dry weight of soil. The other set of soil sample (taken at about $1.5 \mathrm{~kg}$ ) was air dried and sieved $(<2 \mathrm{~mm}$ ) for analysis. Soil particle-size distribution was analyzed with a Bouyoucos hydrometer method, thus enabling soil texture determinations (Gee and Bauder 1986). Soil pH and electrical conductivity (EC) was estimated using water suspension (Thomas 1996; Rhoades 1996). Total lime content was measured with Scheibler calcimeter. Total $\mathrm{C}$ concentrations were analyzed using a dry combustion method in a LECO CNS 2000 Carbon Analyzer (Nelson and Sommers 1996). Total soil N was analyzed after samples were digested using the micro-Kjeldahl method (Kjeltec Auto 1030 Model) (Nelson and Sommers 1996; Bremner 1996). Total soil P was determined using a Spectronic 20D Colorimeter after the samples were first digested in nitric and perchloric acid (Kuo 1996). Exchangeable cations ( $\mathrm{K}, \mathrm{Ca}$, and $\mathrm{Mg}$ ) were extracted with ammonium acetate (Suarez 1996). Calcium and $\mathrm{Mg}$ were determined using a Perkin-Elmer 3110 Atomic Absorption Spectrometer (Wright and Stuczynski 1996). Potassium was determined using a Jenway Flame Photometer. Cation exchange capacity (CEC) was determined from $\mathrm{NH}_{4} \mathrm{OAc}$ extraction (Sumner and Miller 1996).

In mid-summer of 2014 when the plants reached the highest growth, 5 plants from each plot was uprooted using a shovel, placed in paper bags and carried to the lab to determine biomass 
accumulations. Upon returning to the lab, the plant samples were gently immersed in a water bucket to remove the soils attached to the root surface. The samples were dried to constant weight (about 48 hours) at $65 \mathrm{C}^{0}$. Then the above-ground and below-ground parts of the plants were weighed separately. Projected specific leaf area is measured in lab with a portable leaf area meter (LI-3100C Area Meter from Li-Cor).

Volumetric water content of the soil were recorded at a $20 \mathrm{~cm}$ soil depth for ten randomly located spots on beds using a time domain reflectometer (TDR) ((Soil moisture Equipment Corp. Time Domain Reflectometry 6050X3K5B; Rhoades and Oster 1986) several times from May till September in both years.

\subsection{Statistical analysis}

The field emergence rate and biomass growth were tested with an analysis of variance (ANOVA) procedure for a randomized block design. To investigate the relationship among plant variables and soil variables Person correlation procedure was used. SAS was used for all statistical analyses (SAS Institute Inc. 1996). Results for ANOVA were considered significant at $P<0.05$. Tukey's HSD test with alpha $=0.05$ was performed to compare the total biomass means.

\section{Results}

Out of fifteen species, only Brassica nigra and Peganum harmala seeds showed field emergence from 2012 fall sowing. For the spring 2013 sowing, Onobrychis, Reseda, Marrubium, Atriplex, Glaucium, Brassica, Peganum, Teucrium, Vicia and Stachys species had successfull field emergence rate. For the next year trials, the species that showed successful field emergence rate in the previous year were used. For the following year, October of 2013 and in April of 2014, seeds of Brassica, Peganum, Onobrychis, Reseda, Marrubium, Atriplex, Glaucium, Teucrium, Vicia and Stachys were sown again on the beds. Field control in May of 2014 showed that Atriplex, Peganum, Stachys, Marrubium, Glaucium, Teucrium, Salvia, Onobrychis, Reseda and Vicia had successful field emergence rates. The field emergence and ground cover rates of the species varied between 15-24 and 60-70\%, respectively. The field emergence rates and ground cover percentages were not significantly different among these species (Table 4)

The results of the data indicate no relations of seed germination with soil $\mathrm{CEC}, \mathrm{pH}$, and nutrient variables. All of the sites have high lime content. EC values in all sites are considered below the critical value (4 dS $\left.\mathrm{m}^{-1}\right)$. Soil organic matter (OM) and nutrient content are very low. Due to higher variation within sites no significant variation were measured among the sites for any of the soil variables. The field emergence values for each germinated species were not significantly different among the sites. However, some of the species' seedlings with successful emergence rates did not survive during summer drought. The seedlings were desiccated on certain spots on each bed. TDR measurements showed that the volumetric water content of soils on the first $20 \mathrm{~cm}$ depth drops to around $10 \%$ in all treatments by mid May.

Statistical analysis showed that growth of the species also is not related to soil variables. For each species biomass measurements did not make significant differences among the sites. Atrpilex, 
Onobrychis and Vicia showed the best growth rates in all sites. These species produced about two times more biomass compared to the mean biomass of the Peganum, Reseda and Marrubium (Fig 2). Biomasss and ground cover per seedlings for Atriplex ( $P$-value $=0.0001)$, marrubium ( $P$-value $=0.0007)$, peganum (P-value $=0.001)$, reseda $(P$-value $=0.0021)$ and teucrium $(P$-value $=0.0002)$ were significantly related (Figure 3a, b, c, d, e).

Individual seedling weight (P-value= 0.0001), ground cover area $(P$-value $=0.0001)$ and SLA values $(P$ value $=0.0021$ ) were significantly different among the emerged species. Atriplex and peganum had the highest biomass and largest ground cover area per seedling. On the otherhand vicia had olmast three times SLA than the other species (Table 5)

\section{Discussion}

In addition to climatic and edaphic constrains to plant growth, clearing for cultivation of cereals, firewood collection from dwarf shrubs, and heavy overgrazing has dramatically degraded the Irano-Turanian Phytogeographic provinces of Turkey. Even though plantation practices have been carried out for about six decades in the region, tree-oriented plantation practices have shown limited success. Naeem (2006) stated that if nutrient cycling or productivity is adversely influenced it might hinder restoration. Therefore in these severely degraded ecosystems, restoration projects might aim to restore different functional groups for the ramping up of species and increase the diversity. If herb species are used as part of an overall restoration strategy, they may modify microclimate and edaphic conditions in ways that favor establishment of woody species (Rhoades et al. 1998).

However, low rainfall and its poor distribution together with prolonged hot and dry periods have caused difficult environmental conditions for germination, field emergence and establishment of species naturally. On the otherhand if the disturbance is removed, the degraded ecosystems may initiate a progressive succession to the primitive community, and restoration process is then considered as a progressive succession (Zerga 2015). Early seral vegetation grows through different stages while it is improving the function of the ecosystem by providing physical soil protection against erosion by reducing the velocity of runoff and its decomposition, and this contributes to nutrient cycling. However, when insufficient plant populations have remained on the site, natural revegetation is slow in many areas. Enclosure usually permits the restoration and biological recovery of vegetation structure, composition, biomass, and productivity in a time span of 35 years or more in steppic ecosystems (Le Houerou 2000). Therefore, species adapted to sowing are often desirable for a successful restoration (Vallentine, 1989). Enclosing the site and applying some cultural practices such as tilling may create favorable microsites to enable seeds to germinate and establish more successfully (Gebremeskel and Pieterse, 2008).

Over the years, thousands of hectares have been established artificially in Morocco, Iran, Australia, Tunusia, Algeria (Rhoades et al. 1998; Koocheki 1996). For the current study, fifteen species were collected from fenced afforestation sites. Out of fifteen species, Atriplex, Peganum, Stachys, Marrubium, Glaucium, Teucrium, Salvia, Onobrychis, Reseda and Vicia had successful field emergence rates. 
The results of the data indicate no relations of seed germination with soil chemical variables. All of the sites have high lime content. Even though EC value in Acıpınar sites in almost ten times more than the value for the other sites, the soil salinity on all sites is considered below the critical value (Richards 1954). Soil organic matter (OM) and nutrient content are very low. Since the variations on seed size, rooth length, SLA etc are very high among the species, such plant traits don't seem to explain field emergence and survival rates. Therefore it is asumed that the main factor on seedling growth on this region is available mositure in the rooting depth. The seedlings were desiccated on certain spots on each bed in couple of weeks after emergence. The reason for the desiccation of seedlings can be partially attributed to germination in the fixed soil depth for moisture uptake. When this soil layer gets dry at the beginning of the summer, the roots which explore the deeper soil horizon may have better soil moisture availability but when the roots did not explore the lower soil horizons the plants may experience severe drought stress. TDR measurements showed that the volumetric water content of soils on the first $20 \mathrm{~cm}$ depth drops to around $10 \%$ in all treatments by mid May. This value is much below the available water content needed for plant growth in these soils.

But in nature the seeds fall on different soil layers and many of them deteriorate but only those which find the best microclimate for that season can thrive. Harper et al. (1965) claimed that seed germination and establishment of natural and artificial revegetation is a result of the number of seeds favorable in microsites or safe sites in the seedbed. Thus, varied micro-environments provided on a soil surface act selectively on seed populations and determine the numbers of safe germination sites (Harper et al. 1965).

Because of the yearly variations in the rain patterns and soil warming it is not possible to provide a practical suggestion to the practitioners. Many of the species not grown in open areas grow successfully in the fenced and tilled experimental sites. Thus even natural recovery of the vegetation can still contribute significantly to the early restoration process of the sites providing enough protection and soil condition. Therefore, tilling and fencing large areas may start natural restoration of the plant communities. But it may take several years for these species to have enough cover on the ground. The process can be accelerated artificially and modified according to the restoration program in the region. The results of the current study indicate that leveling the surface for seedbeds may reduce the diversity of the soil microclimate and it is risky for germination and growth. Thus, instead of having smooth soil surface, rough surfaces may provide uneven depth and secure the enough germination and growth success by simulating the natural distribution of the seeds in different layers of the soil.

Atrpilex, Onobrychis and Vicia showed the best growth rates in all sites. These species produced about two times more biomass compared to the mean biomass of the Peganum, Reseda and Marrubium (Fig 2). In addition, Atrpilex produced plenty of seeds by the mid-summer and it was infested by wild animals (especially rabbits). Results of this experiment are similar to the others reported from different arid regions for Atriplex. Atriplex species are used extensively in different regions for aridland and rangeland restoration. Mohebbi et al. (2014) reported that Atriplex species have been used extensively due to the high palatability and high forage value in Iran. Atriplex canesence provides excellent browse for wildlife and is highly palatable for most livestock and big game (Mohebbi et al 2013; 2014). 


\section{Conclusions}

Results of the experiment imply that Atriplex, Onobrychis, Vicia, Stachys, Teucrium, Glaucium, Peganum, Reseda and Marrubium are the most promising species to use as ground-cover for ecosystem restoration practices in the region. Since Atriplex hold the soil strongly and provide food for animals this species can be used in restoration practices for both soil protection and wildlife promotion services.

Further studies are needed about the species which showed germination success. Experiments should be conducted to measure the performance of the seed germination and growth rate for different seeding depth. Using varying seeding depth may guarantee enough seedlings on the ground. Those ploughing should create different clumps on the surface and these clumps should not be broken up to create more homogeneous surface.

Field observations showed that fencing the sites to protect them from grazing pressure promoted the germination and growth of the some of the ground cover vegetation. Certain manipulations such as adding seeds of species that are not naturally present in the site and that have showed emergence success and also removing some of the more competitive species already on the site may accelerate the restoration process. Enriching the soil organic matter and nutrient content through establishing early seral stages may facilitate the subsequent afforestation practices.

\section{Declarations}

\section{Acknowledgements}

This study was funded by TÜBITAK (The Scientific and Technological Research Council of Turkey) through project no: 1120946 and titled as "Survival, Growth and Nutritional Status of Different Tree, Shrub and Herb Species and Their Effects on Some of the Soil Properties in the Central Arid Region of Turkey" titled . Duzce University BAP program (DÜBAP 2012.05.01.113).

Conflict of interest: On behalf of all authors, the corresponding author states that there is no conflict of interest.

\section{References}

Atalay í. 2002. Türkiye'nin Ekolojik Bölgeleri. [Ecological regions of Turkey]. Meta Basimevi, Izmir, Turkey. [In Turkish].

Balcı N. 1978. Kurak ve Nemli İklim Koşulları Altında Gelişmiş Bazı Orman Topraklarının Erodibilite Karakteristikleri. [Erodibility characteristics of soils developed under arid and semi-arid conditions]. İstanbul Üniversitesi Orman Fakültesi Yayınları. I.Ü. Yayın No: 2402. O.F. Yayın No: 248., İstanbul. [In Turkish].

Birkmann R. 1976. Geology of Turkey. Elsevier Scientific Publishing Company, New York. 
Brady N C, Weil R R. 1999. The Nature and Properties of Soils. Twelfth Edition. Prentice Hall, New Jersey.

Bremner J M. 1996. Nitrogen- Total. In: Sparks, D.L. (Eds.) Methods of Soil Analysis - Part 3 - Chemical Methods. Soil Science Society of America, American Society of Agronomy, Madison, Wisconsin, pp. 10851121.

Buol S W, Hole F D, McCracken R J. 1989. Soil Genesis and Classification, $3^{\text {rd }}$ Ed. Iowa State University Press, Ames.

Ceylan A, Akgündüz S, Demirörs Z, Erkan A, Çınar S,Özevren. 2009. I. Ulusal Kuraklık ve Çölleşme Sempozyumu. [National aridity and desertification symposium]. 16-18 Haziran, Konya [In Turkish].

Çepel N. 1995. Yok ettiğimiz ormanlarımız kaybolan fonksiyonel değerler ve zamanımızın orman ölümleri. [Forests we eradicated, functional values we lost and current forest diebacks]. TEMA Vakfı Yayınları, 2, İstanbul [In Turkish].

Çetik A R. 1985. Türkiye Vegetasyonu: 1. İç Anadolu'nun Vejetasyonu ve Ekolojisi. [Vegetation of Turkey. I. Vegetation and ecology of Central Anatolia]. Selçuk Üniversitesi Yayınları No:7, Fen Edebiyat Fakültesi Yayınları No:1 [In Turkish].

Dregne H E. 1976. Soils of arid regions. Developments in soil science 6. Elsevier Scientific Publishing Company, Amsterdam.

Day T A and Detling JK. 1994. Water relations of Agropyron smithii and Bouteloua gracilis and community evapotranspiration following long-term grazing by praire dogs. Am. Midland Naturalist. 132: 381-392.

Fanning D S, Fanning M C B. 1989. Soil morphology, genesis and classification. John Wiley and Sons, New York.

Gebremeskel K and Pieterse P J. 2008. The Effects of mulching and fertilizing on growth of over-sown grass species in degraded rangeland in north-eastern Ethiopia. African Journal of Range Forage Science. 25(1): 37-41.

Gee G W, Bauder J W. 1986. Particle-size analysis. In: Knute A. (ed.) Methods of soil analysis. Part 1 Physical and mineralogical analysis. $2^{\text {nd }}$ ed. American Society of Agronomy and Soil Science Society of America, Madison, Wisconsin. p. 383-411.

Harper J L, Williams J T and Sagar G R. 1965. The behaviour of seeds in soil. I. The heterogeneity of soil surfaces and its role in determining the establishment of plants from seed. Journal of Ecology 53: 273286.

Heske F. 1952. Stepten Faydalanma İmkanları, Türkiye'de Ormanların Korunması, Kuraklıkla Mücadele ve İç İskan Meselelerinin Planlaştııılması Hakkında Düşünceler. [Ways to benefit from steppe, Forest 
protection, combating to drought of settlement problems]. Kader Basımevi, İstanbul. [In Turkish].

Hillel D. 1998. Environmental soil physics. Academic Press. New York.

Irmak A. 1963. Türkiye'de ormanın yetişmesine hakim olan genel faktörler ve Türkiye'de ağaçlandırmalardaki ekolojik problemler. [Factors affecting forest growth in Turkey and ecological problems on plantations in Turkey]. İstanbul Üniversitesi Yayınlarından No. 1037. Orman Fakültesi No. 92. İstanbul [In Turkish].

Kapur S, Akça E, Özden D M, Sakarya N , Çimrin K M, Alagöz U, Ulusoy R, Darıcı C, Kaya Z, Düzenli S, Gülcan H. 2002. In: Jones R.J.A., Montanarella L. (eds.) The JRC enlargement action. Land degradation. 5-6 December, Ispra, Italy.

Koocheki A.1996. Potential of saltbush (Atriplex spp.) as a fodder shrub for the arid lands of Iran. Fodder shrub development in arid and semi-arid zones. Volume 1. Proceedings of the Workshop on Native and Exotic Fodder Shrubs in Arid and Semi-arid Zones, 27 October-2 November 1996, Hammamet, Tunisia 2000 pp. 178-183

Kuo S. 1996. Phosphorus. In Methods of Soil Analysis - Part 3 - Chemical Methods, pp. 869-919. Eds D L Sparks et al. Madison, Wisconsin, USA: Soil Science Society of America and American Society of Agronomy.

Le Houerou HN. 2000. Restoration and Rehabilitation of Arid and Semiarid Mediterranean Ecosystems in North Africa and West Asia : A Review. Arid Soil Research and Rehabilitation. 14 :3 14, 2000

Marsdena S J, Fieldingb A H, Meadb C, Zakaria M H. 2002. A technique for measuring the density and complexity of understorey vegetation in tropical forests. Forest Ecology and Management 165: 117-123

Mohebbi A, Jafari M, Tavili A, Javadi S A, Esfahan E Z and Ramezani M. 2013. Effect of Livestock Grazing on Growth Characteristics of Atriplex Canescens. Desert 17: 299-303

Mohebbi A, Jafari M, Tavili A, Javadi S A, Esfahan E Z and Ramezani M. 2014. Comparison of Seed Characteristics in Even-aged Accessions of Atriplex canescens under Exclosure and Non-exclosure Conditions in Rangelands of Zarand-Shahriar, Iran. Ecopersia. 2(1): 419-426

Naeem S. 2006. Biodiversity and Ecosystem Functioning in Restored Ecosystems: Extracting Principles for a Synthetic Perspective. In: Foundations of Restoration Ecology. Edited by. Donald A. Falk, Margaret A. Palmer and Joy B. Zedler. Island Press. London.

Nelson DW, Sommers L E. 1996. Total carbon, organic carbon, and organic matter. In Methods of soil analysis - Part 3 - Chemical methods, pp. 961-1010. Eds D L Sparks et al. Madison, Wisconsin, USA: Soil Science Society of America and American Society of Agronomy. 
Özhatay N, Byfield A, Atay S. 2003. Türkiye'nin önemli bitki alanları. [Important plant areas of Turkey].WWF Türkiye (Doğal Hayatı Koruma Vakfı), İstanbul [In Turkish].

Özyuvacı N. 1999. Meteoroloji ve klimatoloji. [Meteorology and climatology]. i.ü. Orman Fakültesi Yayınları, Fakülte Yayın No. 460, İstanbul [In Turkish].

Patten M A 1997. Reestablishment of rodent community in restored desert scrub. Restoration Ecology. 5:156-161

Rhoades J.D. (1996). Salinity: electrical conductivity and total dissolved solids. In: Sparks D.L., Page A.L., Helmke P.A., Loeppert R.H., Soltanpour P.N., Tabatabai M.A., Johnston C.T., Sumner M.E. (eds.) Methods of soil analysis - Part 3. Chemical methods. American Society of Agronomy and Soil Science Society of America, Madison, Wisconsin. p. 417-435.

Rhoades C C, Eckert G E and Coleman D C. 1998. Effects of pasture tree on soil nitrogen and organic matter. Implications for tropical montane forest restoration. Restoration Ecology. 6:262-270

Richards L A 1954. Diagnosis and improvement of saline and alkali soils. United States Department of Agriculture. Soil and Water Conservation Research Branch, Agricultural Research Service. Agriculture Book No. 60, Washington, D.C.

SAS Institute, Inc. 1996. SAS/STAT users guide, Version 6.12. SAS Institute, Cary, North Carolina.

Suarez D L. 1996. Beryllium, magnesium, calcium, strontium and barium. In Methods of Soil Analysis Part 3 -Chemical Methods, pp. 575-601. Eds. D L Sparks et al. Madison, Wisconsin, USA: Soil Science Society of America and American Society of Agronomy.

Sumner M E, Miller W P. 1996. Cation exchange capacity and exchange coefficients. In: Sparks D.L., Page A.L., Helmke P.A., Loeppert R.H., Soltanpour P.N., Tabatabai M.A., Johnston C.T., Sumner M.E. (eds.) Methods of Soil Analysis - Part 3 - Chemical methods. Soil Science Society of America and American Society of Agronomy, Madison, Wisconsin. p.1201-1229.

Thirgood JV. 1981. Man and Mediterranean Forest. A history of resource depletion. Academic Press, New York.

TC Çevre ve Orman Bakanlığı. 2005. Çölleşme ile Mücadele Türkiye Ulusal Eylem Programı. [National action program to combat desertification]. Çölleşme ile Mücadele Ulusal Koordinasyon Birimi, Ankara [In Turkish].

T.C. Çevre ve Orman Bakanlığı. 2008. Ağaçlandırma ve Erozyon Kontrolü Seferberliği Eylem Planı 20082012. [Afforestation and Erosion Control Mobilization Action Plan 2008-2012]. Ankara [In Turkish].

Thomas G W. 1996. Soil pH and soil acidity. In: Sparks D.L., Page A.L., Helmke P.A., Loeppert R.H., Soltanpour P.N., Tabatabai M.A., Johnston C.T., Sumner M.E. (eds.) Methods of soil analysis - Part 3. 
Chemical methods. American Society of Agronomy and Soil Science Society of America, Madison, Wisconsin. p. 475-490.

Tunçdilek N. 1987. Geoekoloji'nin Temel Illkeleri, Doğal Bölgeler. [Principles of Geoecology]. İstanbul Üniversitesi, Deniz Bilimleri ve Coğrafya Enstitüsü. Edebiyat Fakültesi Basımevi, İstanbul. [In Turkish]

Uslu S. 1971. Türkiye'deki Kurak Sahalarda Erozyon Kontrolü ve Vejetasyon Örtüsü. [Erosion control and vegetation cover in aridlands of Turkey] i.ü. Orman Fakültesi Dergisi, A-21(2): 21-33, İstanbul. [In Turkish]

Vallentine J F. 1989. Range development and Improvements, 3rd ed. Academic Press, New York, USA

Varnamkhasti A S, Milchunas D G, Lauenroth W K and Goetz H. 1995. Production and rain use efficiency in short-grass steppe: grazing history, defoliation, and water resource. Journal of Vegetation Science. 6: 787- 796.

Walter H. 1970. Vegetationszonen und Klima. Stutgard, E. Ulmer.

Wright R J, Stuczynski T. 1996. Atomic absorption and flame emission spectroscopy. In: Sparks D.L., Page A.L., Helmke P.A., Loeppert R.H., Soltanpour P.N., Tabatabai M.A., Johnston C.T., Sumner M.E. (eds.) Methods of Soil Analysis - Part 3 - Chemical methods. Soil Science Society of America and American Society of Agronomy, Madison, Wisconsin. p. 65-90.

Zerga B. 2015. Rangeland degradation and restoration: A global perspective. Point Journal of Agriculture and Biotechnology Research. 1(2): 37-54.

\section{Tables}

Table 1. Mean \pm stderr of the soil pH, CEC $\left(\mathrm{Cmol}_{\mathrm{C}} \mathrm{kg}^{-1}\right)$, Total lime (\%), EC ( $\left.\mathrm{dS} \mathrm{m}^{-1}\right)$ and OM (\%) for the first $20 \mathrm{~cm}$ soil depth sampled from experimental plots conducted to study the potential usage of some of the ground-cover vegetation for ecosystem restoration practices in Central Anatolian Region of Turkey.

\begin{tabular}{|llllll|}
\hline Sites & $\mathrm{pH}$ & \multicolumn{1}{c}{$\mathrm{CEC}$} & $\begin{array}{c}\text { Total lime } \\
\left(\mathrm{cmol}_{\mathrm{C}} \mathrm{kg}^{-1}\right)\end{array}$ & $\begin{array}{c}\left.\mathrm{EC}(\mathrm{dS} \mathrm{m})^{-1}\right) \\
\text { OM (\%) }\end{array}$ & \\
\hline Acıpınar & $7.9 \pm 0.25$ & $36 \pm 5$ & $24 \pm 7$ & $2.29 \pm 0.45$ & $1.2 \pm 0.3$ \\
\hline Incesu & $8.1 \pm 0.18$ & $37 \pm 7$ & $25 \pm 6$ & $0.27 \pm 0.02$ & $0.2 \pm 0.2$ \\
\hline Sazlıpınar & $7.8 \pm 0.30$ & $22 \pm 7$ & $15 \pm 4$ & $0.29 \pm 0.02$ & $1.3 \pm 0.1$ \\
\hline Emirgazi & $7.9 \pm 0.23$ & $30 \pm 11$ & $9 \pm 2$ & $0.30 \pm 0.01$ & $0.8 \pm 0.2$ \\
\hline Karapınar & $7.9 \pm 0.22$ & $33 \pm 8$ & $45 \pm 10$ & $0.32 \pm 0.01$ & $2.1 \pm 0.1$ \\
\hline
\end{tabular}


Table 2. Mean \pm stderr of the soil nutrient concentrations for the first $20 \mathrm{~cm}$ soil depth sampled from experimental plots conducted to study the potential usage of some of the ground-cover vegetation for ecosystem restoration practices in Central Anatolian Region of Turkey.

\begin{tabular}{|c|c|c|c|c|c|c|c|}
\hline \multirow[t]{2}{*}{ Sites } & \multirow[t]{2}{*}{ Total N } & \multirow[t]{2}{*}{$(\%)$} & $\mathrm{P}_{2} \mathrm{O}_{5}$ & $\mathrm{Ca}$ & $\mathrm{Mg}$ & K & $\mathrm{Na}$ \\
\hline & & & (ppm) & \multicolumn{4}{|c|}{$\ldots \ldots \ldots \ldots\left(\mathrm{cmolc} \mathrm{kg}{ }^{-1}\right) \ldots \ldots \ldots \ldots \ldots \ldots$} \\
\hline Acıpınar & $0.06 \pm 0.001$ & & $16 \pm 5$ & $22 \pm 4$ & $10 \pm 4$ & $0.8 \pm 0.3$ & $0.06 \pm 0.01$ \\
\hline İncesu & $0.01 \pm 0.001$ & & $11 \pm 3$ & $15 \pm 5$ & $18 \pm 6$ & $0.32 \pm 0.2$ & $0.08 \pm 0.01$ \\
\hline Sazlıpınar & $0.06 \pm 0.001$ & & $20 \pm 4$ & $17 \pm 7$ & $2.6 \pm 1$ & $0.87 \pm 0.3$ & $0.03 \pm 0.01$ \\
\hline Emirgazi & $0.04 \pm 0.001$ & & $30 \pm 8$ & $24 \pm 8$ & $3.3 \pm 1$ & $0.29 \pm 0.3$ & $0.08 \pm 0.01$ \\
\hline Karapınar & $0.10 \pm 0.002$ & & $60 \pm 21$ & $26 \pm 5$ & $4.2 \pm 1$ & $1.7 \pm 0.6$ & $0.14 \pm 0.01$ \\
\hline
\end{tabular}

Table 3. Mean \pm stderr of thousand seed weight of the collected species to study the potential usage of some of the ground-cover vegetation for ecosystem restoration practices in Central Anatolian Region of Turkey. 


\begin{tabular}{|llc|}
\hline Family & Species & Thousand seed weight (g) \\
\hline Alliaceae & Allium myrianthum Boiss. & $30.246 \pm 3.4$ \\
\hline Amaranthaceae & Salsola ruthenica subsp. ruthenica (lljin) Soo & $10.258 \pm 2.1$ \\
\hline Amaranthaceae & Atriplex hortensis L. & $63.3 \pm 2.5$ \\
\hline Brassicaceae & Alyssum strigosum Banks\&Sol. & $3.57 \pm 0.7$ \\
\hline Brassicaceae & Brassica nigra (L.) K.Koch & $8.21 \pm 1.3$ \\
\hline Fabacaceae & Onobrychis tournefortii (Willd.) Desv. & $23.7 \pm 0.62$ \\
\hline Fabaceae & Vicia cappodicica Boiss. \& Bal. & $43.5 \pm 0.5$ \\
\hline Globulariaceae & Globularia orientalis L. & $2.43 \pm 0.1$ \\
\hline Lamiaceae & Nepeta congesta Fisch.\&C.A.Mey. & $13.81 \pm 2.6$ \\
\hline Lamiaceae & Marrubium parviflorum Fisch.\&C.A.Mey. & $2.56 \pm 0.1$ \\
\hline Lamiaceae & Salvia absconitiflora Greuter\&Burdet. & $38.45 \pm 4.1$ \\
\hline Lamiaceae & Teucrium polium L. & $2.18 \pm 0.1$ \\
\hline Lamiaceae & Stachys cretica L. & $3.83 \pm 0.1$ \\
\hline Resedaceae & Reseda lutea L. & $1.08 \pm 0.05$ \\
\hline Papaveraceae & Glaucium corniculatum (L.) & $4.25 \pm 0.1$ \\
\hline Zygophyllaceae & Peganum harmala L. & $3.11 \pm 0.7$ \\
\hline
\end{tabular}

Table 4. Mean \pm stderr of the seed germination rate (\%) and ground cover rate of the germination seeds on the experimental plots conducted to study the potential usage of some of the ground-cover vegetation for ecosystem restoration practices in Central Anatolian Region of Turkey. The results of variance (ANOVA) procedure for randomized block design were considered significant at $P<0.05$. Means with a common lowercase letter are not significantly different at alpha $=0.05$ according to Tukey's HSD test. 


\begin{tabular}{|llll|}
\hline Family & Species & $\begin{array}{l}\text { Field emergence rate } \\
(\%)\end{array}$ & $\begin{array}{l}\text { Ground cover } \\
(\%)\end{array}$ \\
\hline Amaranthaceae & Atriplex hortensis $\mathrm{L}$. & $19 \pm 6 \mathrm{a}$ & $58 \pm 15 \mathrm{a}$ \\
\hline Fabacaceae & Onobrychis tournefortii (Willd.) Desv. & $17 \pm 6 \mathrm{a}$ & $64 \pm 10 \mathrm{a}$ \\
\hline Fabaceae & Vicia cappodicica Boiss. \& Bal. & $23 \pm 5 \mathrm{a}$ & $70 \pm 12 \mathrm{a}$ \\
\hline Lamiaceae & $\begin{array}{l}\text { Marrubium parviflorum } \\
\text { Fisch.\&C.A.Mey. }\end{array}$ & $19 \pm 5 \mathrm{a}$ & $70 \pm 16 \mathrm{a}$ \\
\hline Lamiaceae & Salvia absconitiflora Greuter\&Burdet. & $19 \pm 6 \mathrm{a}$ & $73 \pm 13 \mathrm{a}$ \\
\hline Lamiaceae & Teucrium polium L. & $18 \pm 7 \mathrm{a}$ & $62 \pm 9 \mathrm{a}$ \\
\hline Lamiaceae & Stachys cretica L. & $16 \pm 5 \mathrm{a}$ & $65 \pm 11 \mathrm{a}$ \\
\hline Resedaceae & Reseda lutea L. & $24 \pm 6 \mathrm{a}$ & $70 \pm 8 \mathrm{a}$ \\
\hline Papaveraceae & Glaucium corniculatum (L.) & $15 \pm 7 \mathrm{a}$ & $68 \pm 12 \mathrm{a}$ \\
\hline Zygophyllaceae & Peganum harmala L. & $23 \pm 5 \mathrm{a}$ & $65 \pm 10 \mathrm{a}$ \\
\hline
\end{tabular}

Table 5. Mean \pm stderr of biomass $(\mathrm{g})$, individual seedling ground cover area $\left(\mathrm{cm}^{2}\right)$ and specific leaf area $\left(\mathrm{SLA}, \mathrm{cm}^{2} \mathrm{~g}^{-1}\right)$ of the species sampled from experimental plots conducted to study the potential usage of some of the ground-cover vegetation for ecosystem restoration practices in Central Anatolian Region of Turkey. The results of variance (ANOVA) procedure for randomized block design were considered significant at $P<0.05$. Means with a common lowercase letter are not significantly different at alpha $=$ 0.05 according to Tukey's HSD test.

\begin{tabular}{|lccc|}
\hline Species & Plant weight (g) & Cover area $\left(\mathrm{cm}^{2}\right)$ & SLA $\left(\mathrm{cm}^{2} \mathrm{~g}^{-1}\right)$ \\
\hline & & & \\
\hline Atriplex hortensisL. & $53.3 \pm 13.5 \mathrm{a}$ & $111 \pm 23 \mathrm{a}$ & $437 \pm 5 \mathrm{e}$ \\
\hline Peganum harmala L. & $50.5 \pm 6 \mathrm{a}$ & $101 \pm 10 \mathrm{a}$ & $858 \pm 12 \mathrm{~b}$ \\
\hline Glaucium corniculatum (L.) & $2.7 \pm 0.3 \mathrm{~b}$ & $13.6 \pm 0.5 \mathrm{~b}$ & $473 \pm 32 \mathrm{~d}$ \\
\hline Marrubium parviflorum Fisch.\&C.A.Mey. & $15.7 \pm 1.5 \mathrm{~b}$ & $32.2 \pm 1.7 \mathrm{~b}$ & $685 \pm 4 \mathrm{c}$ \\
\hline Onobrychis tournefortii (Willd.) Desv. & $11.2 \pm 1 \mathrm{~b}$ & $24.9 \pm 1.6 \mathrm{~b}$ & $396 \pm 8 \mathrm{e}$ \\
\hline Reseda lutea L. & $12 \pm 1 \mathrm{~b}$ & $26.2 \pm 2.1 \mathrm{~b}$ & $673 \pm 12 \mathrm{c}$ \\
\hline Stachys cretica L. & $9.5 \pm 1.1 \mathrm{~b}$ & $20.4 \pm 1.1 \mathrm{~b}$ & $435 \pm 3 \mathrm{ed}$ \\
\hline Teucrium polium L. & $13.2 \pm 1.8 \mathrm{~b}$ & $29.2 \pm 3.2 \mathrm{~b}$ & $367 \pm 5 \mathrm{e}$ \\
\hline Vicia cappodicica Boiss. \& Bal. & $17.3 \pm 2.2 \mathrm{~b}$ & $32.9 \pm 3.3 \mathrm{~b}$ & $1077 \pm 13 \mathrm{a}$ \\
\hline
\end{tabular}




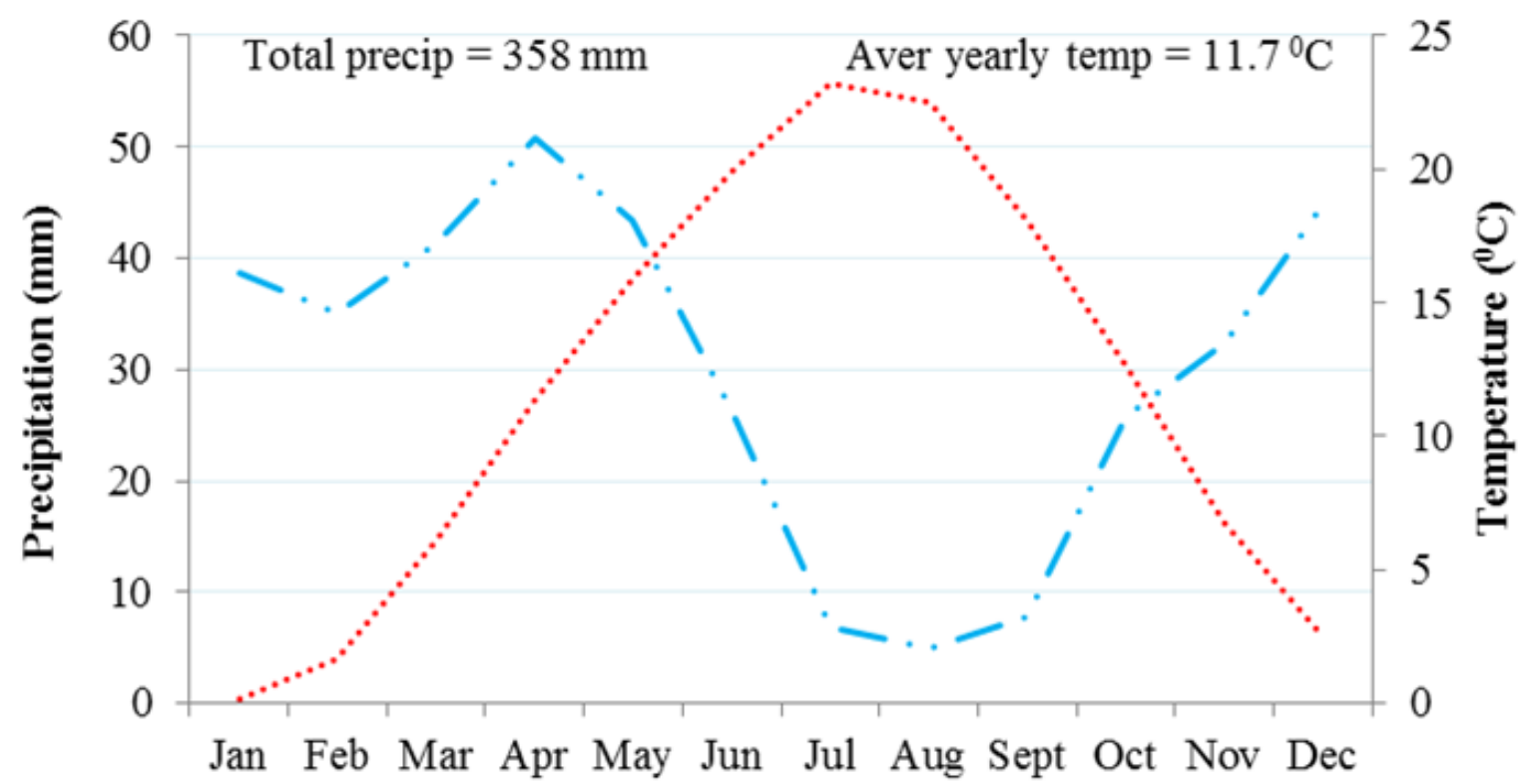

Months

a.

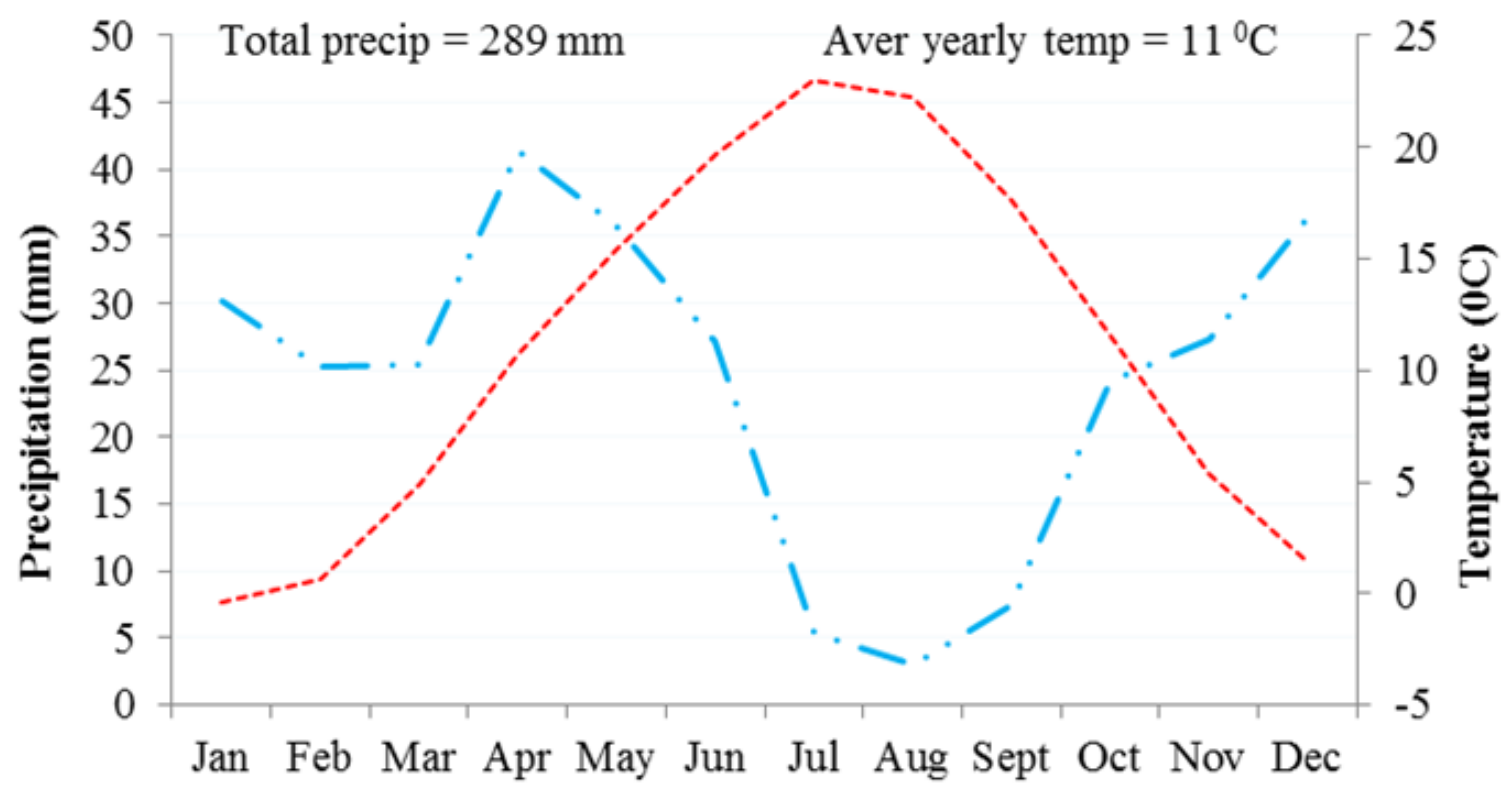

Months

b.

\section{Figure 1}

a. Walter diagram for Acıpınar and Incesu experimental sites established to study the potential usage of some of the ground-cover vegetation for ecosystem restoration practices in Central Anatolian Region of Turkey. b. Walter diagram for Karapınar, Emirgazi and Sazlıpınar experimental sites established to study 
the potential usage of some of the ground-cover vegetation for ecosystem restoration practices in Central Anatolian Region of Turkey.

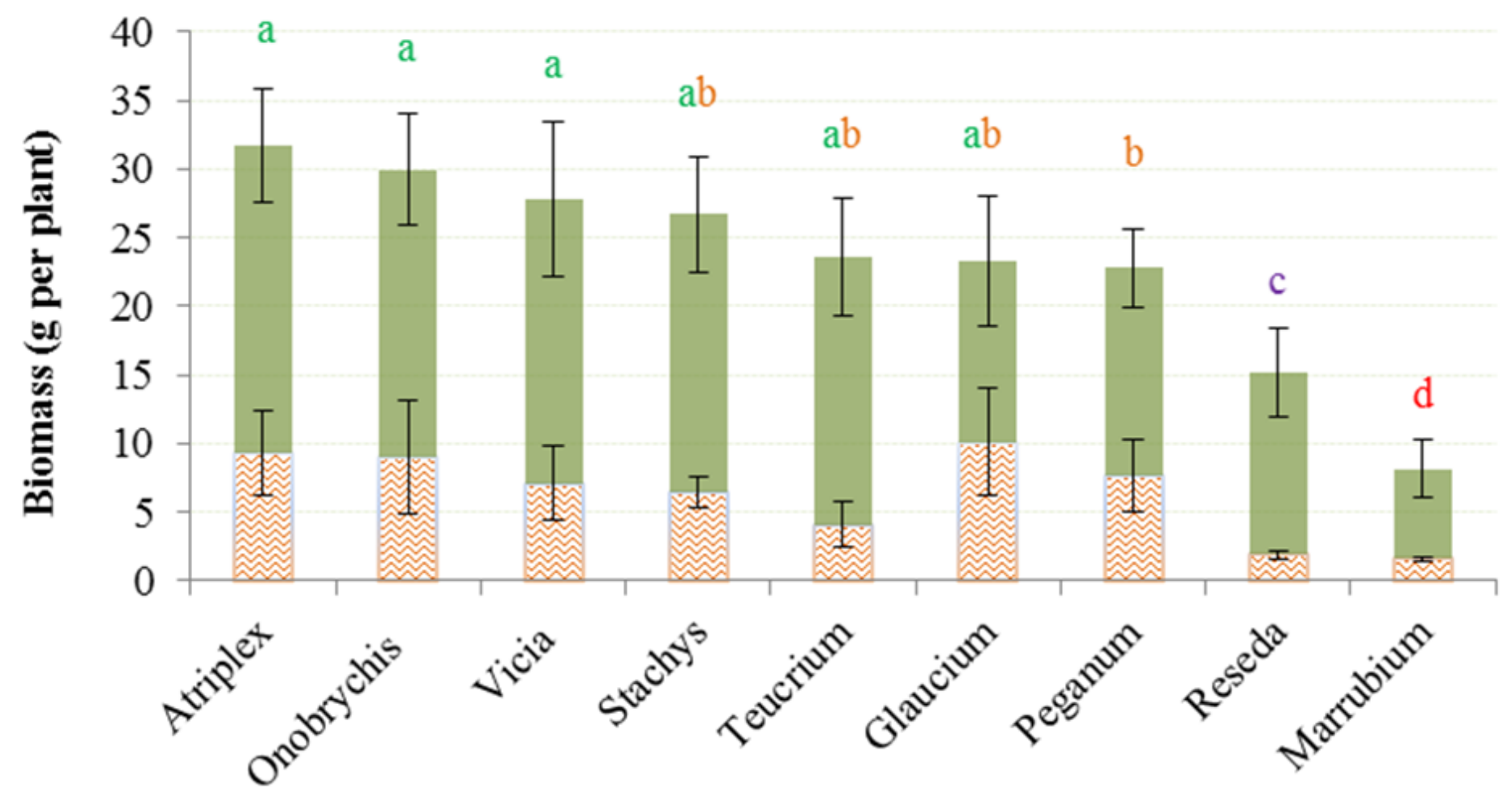

Species

\section{Figure 2}

Means and S.E. of biomass for different species sampled from experimental plots conducted to study the potential usage of some of the ground-cover vegetation for ecosystem restoration practices in Central Anatolian Region of Turkey. Means with a common lowercase letter are not significantly different. For each species upper part of the column represent aboveground and lower part of the column represents the root biomass 


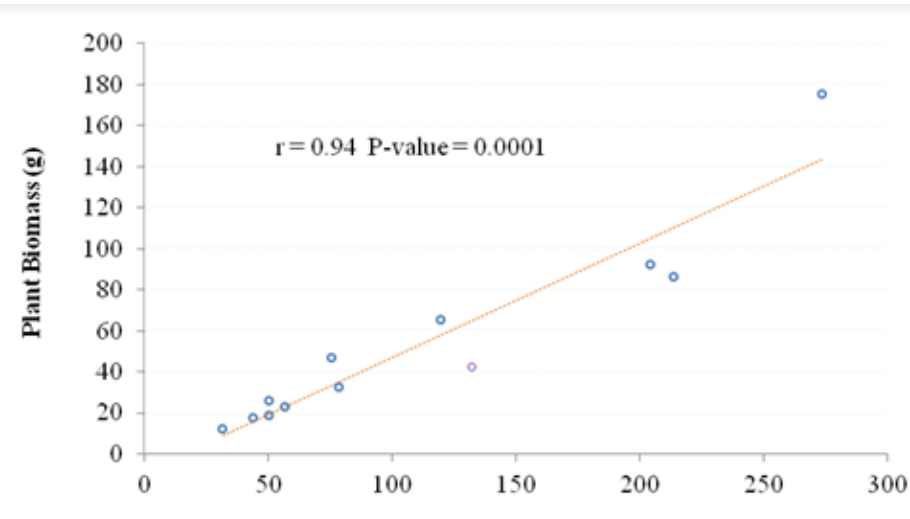

a

Ground Cover (cm²)

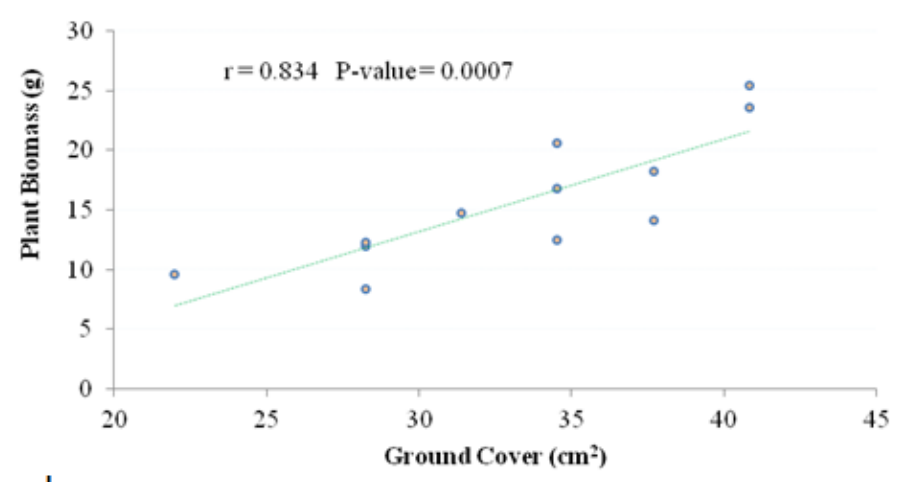

b
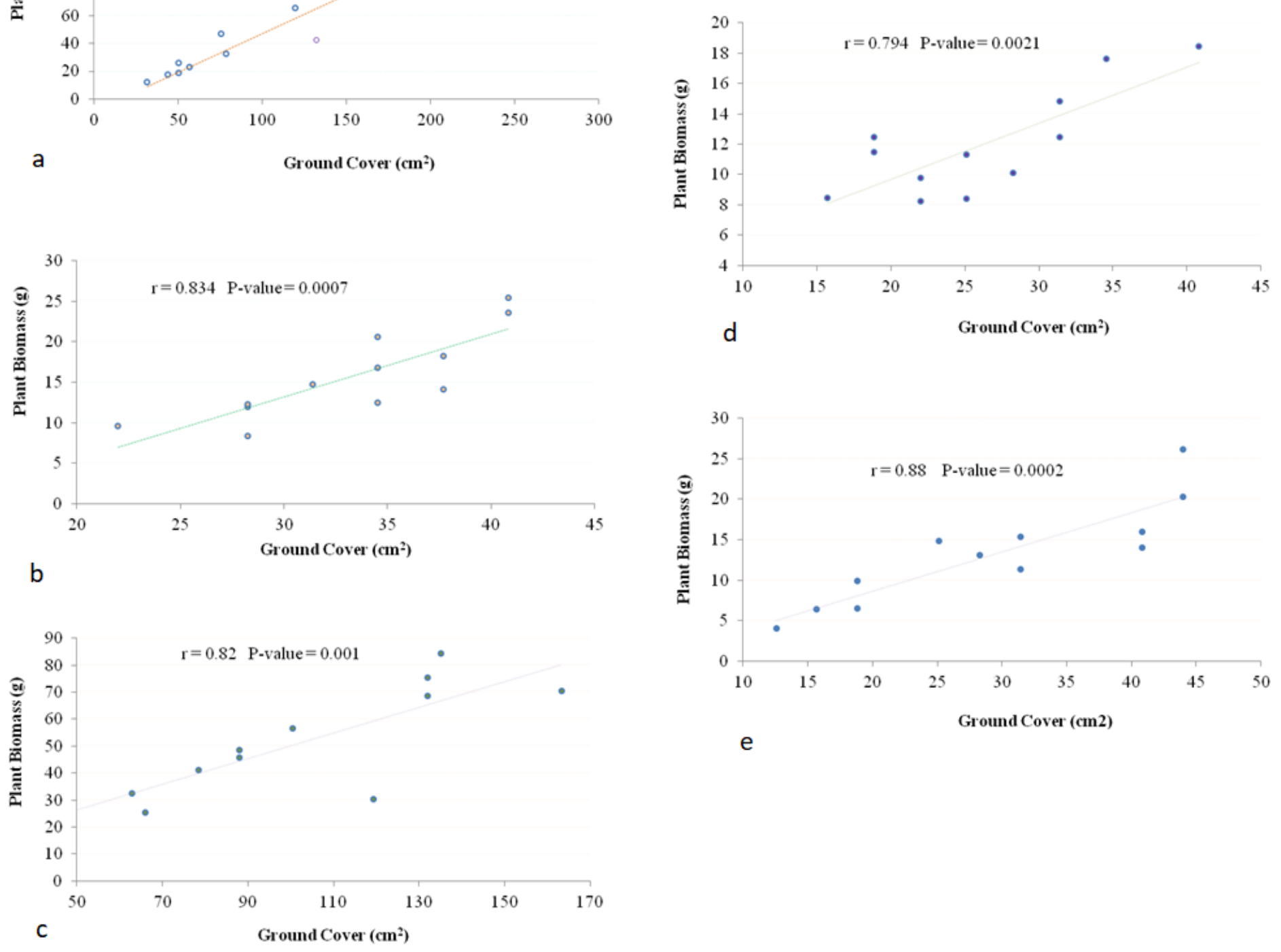

\section{Figure 3}

a. Correlation between plant biomass $(\mathrm{g})$ and its ground cover area $(\mathrm{cm} 2)$ of Atriplex hortensis sampled from experimental plots conducted to study the potential usage of some of the ground-cover vegetation for ecosystem restoration practices in Central Anatolian Region of Turkey. b. Correlation between plant biomass $(\mathrm{g})$ and its ground cover area $(\mathrm{cm} 2)$ of Marrubium parviflorum sampled from experimental plots conducted to study the potential usage of some of the ground-cover vegetation for ecosystem restoration practices in Central Anatolian Region of Turkey. c. Correlation between plant biomass $(\mathrm{g})$ and its ground cover area $(\mathrm{cm} 2)$ of Peganum harmala sampled from experimental plots conducted to study the potential usage of some of the ground-cover vegetation for ecosystem restoration practices in Central Anatolian Region of Turkey. $\mathrm{d}$. Correlation between plant biomass $(\mathrm{g})$ and its ground cover area $(\mathrm{cm} 2)$ of Reseda lutea sampled from experimental plots conducted to study the potential usage of some of the ground- 
cover vegetation for ecosystem restoration practices in Central Anatolian Region of Turkey. e. Correlation between plant biomass $(\mathrm{g})$ and its ground cover area $(\mathrm{cm} 2)$ of Teucrium polium sampled from experimental plots conducted to study the potential usage of some of the ground-cover vegetation for ecosystem restoration practices in Central Anatolian Region of Turkey. 